\title{
New Late Jurassic symmetrical hermit crabs from the southern Polish Uplands and early paguroid diversification
}

René H.B. Fraaije, Wiesław Krzemiński, Barry W.M. Van Bakel, Ewa Krzemińska, and John W.M. Jagt Acta Palaeontologica Polonica 59 (3), 2014: 681-688 doi: http://dx.doi.org/10.4202/app.2012.0022

On the basis of carapaces, three new genera and species of symmetrical paguroid anomurans are described. Diogenicheles theodorae, Masticacheles longirostris, and Pilgrimcheles karolinae constitute the oldest known members of the family Parapylochelidae. As noted previously, assemblages from sponge-reefal strata of Oxfordian (Late Jurassic) age in the southern Polish Uplands document an important radiation event amongst paguroids. Compared to the present day, the Parapylochelidae were more diverse during the mid-Mesozoic; they appear to have withdrawn from shallow, reefal waters to deep-water settings from the Late Jurassic onwards. Paguroid faunas from the Oxfordian of Europe already are highly diverse, both morphologically and phylogenetically, and comprise early members of the families Diogenidae, Pylochelidae, and Parapylochelidae. This suggests that the evolutionary history of paguroids started much earlier (i.e., in pre-Jurassic times) than previously assumed. New terms for several typical paguroid carapace regions are introduced and on the basis of carapace morphology and ecological shifts hypotheses on the early speciation of hermit crabs are put forward.

Key words: Anomura, Paguroidea, Parapylochelidae, carapace morphology, evolution, Oxfordian, Jurassic, Poland.

René H.B. Fraaije [info@ oertijdmuseum.nl], Oertijdmuseum De

Groene Poort, Bosscheweg 80, NL-5283 WB Boxtel, the

Netherlands; Wiesław Krzemiński [krzeminski@muzeum.pan.krakow.pl

] and Ewa Krzemińska [krzeminska@ isez.pan.krakow.pl], Institute of Systematics and Evolution of Animals, Polish Academy of Sciences, ul.

Sławkowska 17, PL-31-016 Kraków, Poland; Barry W.M. Van Bakel [barryvanbakel@gmail.com ], Oertijdmuseum De Groene Poort, Bosscheweg 80, NL-5283 WB Boxtel, the Netherlands; and, Nederlands Centrum voor Biodiversiteit (Naturalis), P.O. Box 9517, NL-2300 RA Leiden, the Netherlands; John W.M. Jagt [john.jagt@ maastricht.nl], Natuurhistorisch Museum Maastricht, de Bosquetplein 6-7, NL-6211 KJ Maastricht, the Netherlands. 
This is an open-access article distributed under the terms of the Creative Commons

Attribution License (for details please see creativecommons.org), which permits unrestricted use, distribution, and reproduction in any medium, provided the original author and source are credited.

FaF 